\title{
The Policies and Politics of Climate Change: An Evaluative Analysis of the Afforestation Policy of Katsina State in Dutsin-Ma Local Government Area
}

\author{
Orbunde Emmanuel ${ }^{1}$, A. O. Ogoh ${ }^{2}$ \\ ${ }^{1,2}$ Department of Political Science, Federal University Dutsin-Ma, Katsina State \\ eorbunde@fudutsinma.edu.ng,aogoh@fudutsinma.edu.ng
}

\begin{abstract}
The issue of changing weather and climatic conditions has gained wide spread concern among academics, policy Makers, environmental watchers and world leaders across the globe. This is not surprising because every year that passes by leaves behind very worrisome climatic changes with dear negative effect on the continued healthy living of man-kind on earth. It is in the light of this that this paper appreciates the problem of policy and politics of climatic change in Nigeria. The work analyses the political and policy challenges encountered by the Katsina state Government in its efforts to curb the problem of desert encroachment through a massive policy and programme of Afforestation. An evaluative analysis of the policy's success, failures and problem encountered so far from 2010-2013 was carried out in this paper. Findings showed that of the 5,000 trees planted along Dabawa and Darawa areas of Dutsin-Ma Local Government Area of Katsina State, only about 2,500 trees have survived from 2010-2013 so far. This is an achievement on the one side, but it also goes to show that much still needs to be done. The study also observed that cattle's, herdsmen and the locals play certain destructive role to the trees, thereby hampering the efforts of the government. The work also took into cognizance other relevant policies and agencies that are very important in curbing the problem of desertification, these included the ministry of Environment and Agriculture. The paper also observed that, on the part of the Government, there appears to be a lack of commitment to follow up on the continued maintenance of these trees. The paper recommends that unless a massive concerted effort is made to integrate the rural populace in viewing these Aforestation policy as also safe guarding their own health and future environmental wise, the programme or policy will continue to meet these challenges which in the end does not help in curbing the problem of desert encroachment in the state and region.
\end{abstract}

Keywords: Afforestation, Deforestation, Desert encroachment, Policy, Politics.

\section{INTRODUCTION}

Climate change is one of the greatest socioeconomic and biophysical challenges confronting the world in the 21 st century. Human activity, particularly deforestation and the burning of fossil fuels, is driving this change by increasing atmospheric concentrations of carbon dioxide and other greenhouse gases (GHGs) (Abaje and et al, 2015). This changing weather and climatic conditions has continued to gain wide spread concern among academics, policy makers, environmental watchers and world leaders across the globe. This is because, every year comes and goes leaving behind very worrisome climatic changes with dear negative effect on the continued healthy living of mankind on earth.

It is in the light of this that this paper appreciates the problem of policy and politics of climatic change in Nigeria with main focus on the political and policy challenges encountered by the Katsina state government in its efforts to curb the problem of desert encroachment through a massive policy and programme of Afforestation.

The sahelian drought of 1972/73 set into motion the establishment of Afforestation Programmes, the construction of Damns for irrigation and the establishment of appropriate national institutions such as the River Basin Development Authorities, the Forestry Management, Evaluation and Coordinating Committee on Desertification Control (Makire 2009).

The Katsina state government has since keyed into these National policies and programmes by equally developing a number of policies and programmes ranging from Agricultural to energy, environmental to Health etc., all geared towards checking the menace of desertification in the region. A good example is the Katsina Afforestation Project Unit (KTATPU) 


\section{METHODOLOGY OF THE PAPER}

The work made use of aggregate data and statistical information provided by Government agencies such as the Department of forestry, the ministry of Environment and agriculture, the Katsina State Afforestation project Unit (KTAPU) among others. These data were analysed using simple Tables and percentage approach. This method was able to bring out a better appreciation of the enormous challenges of the problem of desert encroachment and the effort of the katsina state Government in curbing the menace.

\section{The Concept of Forest and Afforestation as a Conservative Policy of the ENVIRONMENT}

Forests have since ancient times played an important role in the lives of the people and the environment in general. That is, Forests provided and continue to provide numerous benefits to humanity (Sackey, 2007). Forest performs a wide range of critical environment and climatic functions and it serves as homes to the majority of the world's plant and animals. However, the concern for us in this study is the significance of forest and Afforestation as a conservative method and policy in preserving the ecosystem, i.e checking the menace of desertification, especially in the Sahel region and particularly in Katsina state. According to Abass (2007) the significance of Forest can be classified under environmental, social, and economic importance. Forest over the years played a key role in protecting the environment or the ecosystem in general. They are also important source of reinvestible capital and a source of income. They also serve as a foundation for industrialization and enhances the stability of the rural population. A report prepared by the central Bank of Nigeria (2012) shows that Forestry Contribution to Nigeria's Gross Domestic Product (GDP) are 1.82\% in 2007, $2.04 \%$ in 2008, $1.31 \%$ in 2009 and $1.29 \%$ in 2010 (CBN 2012). This statistics shows a declining situation. Boon et all (2009) stated that the past two decades have witnessed an increased attention by the world community to the issue of conservation and wise use of forest or Afforestation programmes or policies to curb desertification.

\section{Evolving Policies \& Programs of Afforestation As a response to climate CHANGE}

Government has over the years taken cognizance of the multi-sectoral problems of desertification and the changing climatic conditions of the world, especially as it has to do with Nigeria and the affected areas. In this regard, it has developed a number of policies, plans and programmes ranging from agricultural to energy among others to help check this menace of climatic change. These policies have often revolved around National policy on the Environment and the National Agricultural policy. Most state governments affected by the problem of climatic change such as desertification and drought etc in Nigeria have keyed into these national policies and established various policies, plans and strategies of their own to help deal with the challenging changing in climatic conditions of their respective regions.

The Katsina state government presently also has the Katsina State Aforestation project unit (KTAPU), the Katsina state Department of Forestry, with regional or zonal offices in all the 34 local government of the state. There is also the state ministry of Environment and Agriculture among others. The Katsina state Government in conjuction with office of the presidency has also been in partnership with the presidential committee on local production of Artemisinin based combination on therapies located in Koza (chediya) community of the local Government. This Nursery Plantation is a massive boast to checking the menace of desertification as well as providing medicinal benefit to the state and nation at large.

Another example is the Fuel wood plantation project carried out in Rumfa also in Koza by the Katsina state Afforestation project unit, the size of the plantation covers ten hacters of land. The project commenced in July 2013.

\section{IMPORTANT GeO- Informative data OF KATSina State \& Dutsin-Ma Local GOVERNMENT AREA}

Dutsin-ma local government Area is one of the 34 local governments that make up Katsina state. It is bordered by kankia, Basari \& Safana local government Areas. Katsina State itself is located between longitude $6^{\circ} 45^{\prime} \mathrm{E}$ and $8^{\circ} 15^{\prime}$ and latitude $11^{\circ} 20^{\prime} \mathrm{N}$ and $13^{\circ} 20^{\prime} \mathrm{N}$ as seen in figure 1 . It is one of the 
The Policies and Politics of Climate Change: An Evaluative Analysis of the Afforestation Policy of Katsina State in Dutsin-Ma Local Government Area

North West states of Nigeria that shares its Northern border with the maradi, in Niger Republic and Kaduna and Kano states to the south and south east respectively, it also shares border to the East and West with Jigawa and Zamfara states respectively.

According to the 2006 population census figures, katsina state has a population of about 5,801,586 persons and an average growth of $2.8 \%$ (NPC 2006). The climate of katsina state is the "AW" type as determined by Koppen in which distinctive wet and dry seasons are caused by the fluctuations of the ITCZ (Inter Tropical Convergence Zone) or the ITD- South to North (rainy season), vice versa (dry season). The ITCZ separates humid maritime air mass originating from the Atlantic Ocean and dry desert air mass from the Sahara deserts region. Maximum temperature range in Katsina is between $29^{\circ}$ $\mathrm{C}$ and $38^{\circ} \mathrm{C}$, but harmattan season (November to February) lowers temperature to about $18^{\circ} \mathrm{C}$ and $27^{\circ}$ $\mathrm{C}$ in the noon period. (Mohammed, N,D. et aus 2014)

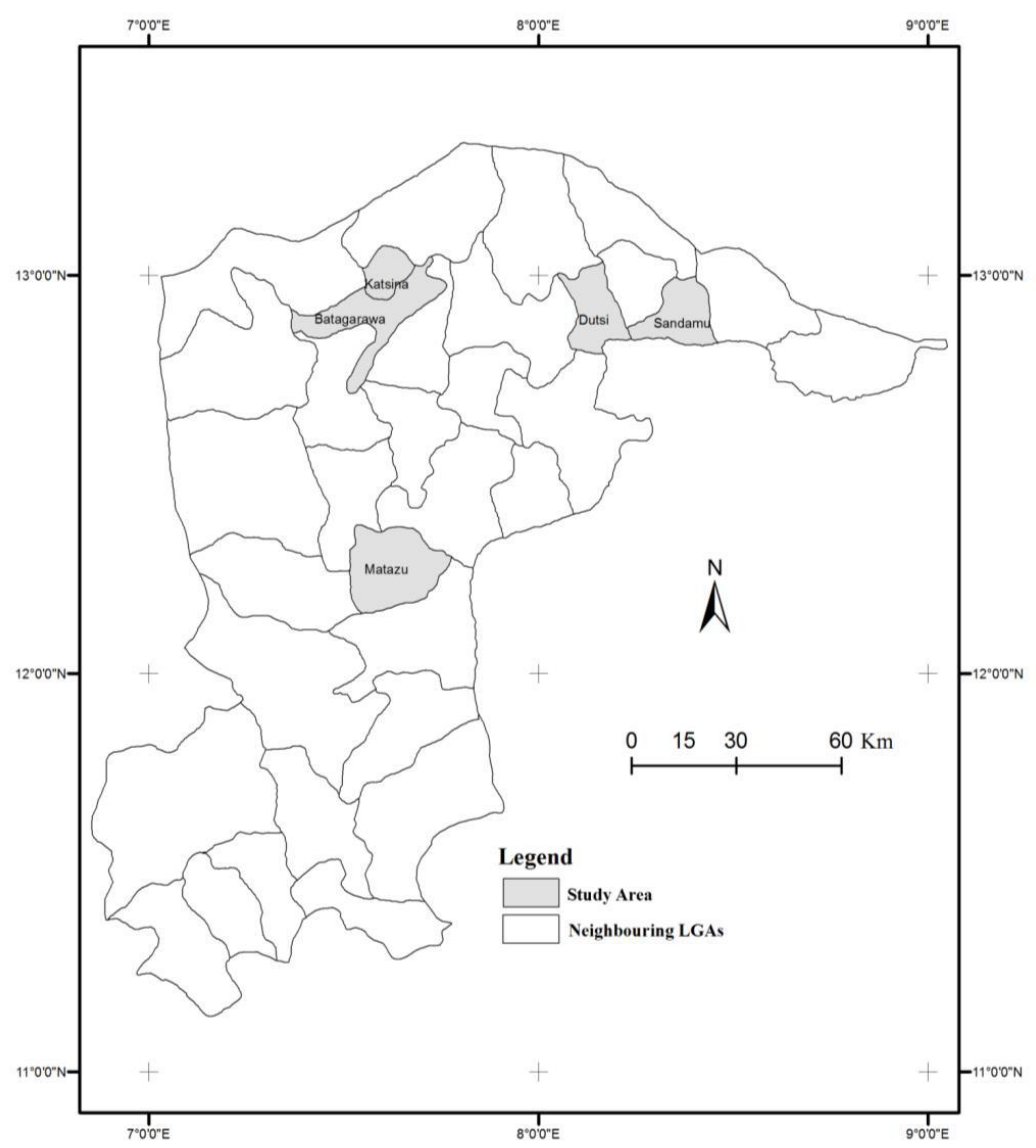

Figure1. Map of Katsina State Showing the Study Area

\section{Policies, Programmes, Agencies and Departments in Katsina State Responsible for Conservative and Environmental Protection}

Katsina state like many other states in the sahel region of Northern Nigeria have equally keyed into the Federal governments National Policy on Forestry and Environmental protection and conservation. Katsina state in its afforestation and environmental Programmes has witness a number of evolving policies aimed at enhancing a better climatic environment for the state.The following are summarized as Afforestation programmes and policies of Katsina state past and present, some of which are partly funded by donor agencies etc.

\subsection{Katsina Agricultural and Rural Development Authority (KTARDA)}

The activities carried out by KTARD includes the establishment of shelter belts, windbreaks and woodlots and biodiversity conservation using Acacia nilotica. This project established a total of 69 shelterbelts in the sahel and sudan ecological zones (Mohammed, 2008). According to Haruna (2010), the Project established a total of 3,470 windbreaks around farmlands and settlements within the study area. It also established a total of 2,229 units of woodlots throughout the zone. This project lasted for a period of five years respectively. (KTRDA, 2009) 


\subsection{European Economic Community/Katsina State Government. (EEC/KTSG)}

This body was established in 1987 and designed appropriate models of agro forestry practice in the Afforestation of Katsina state. A total of 18,674 contact farmers were recruited by this body in the process of carrying out the various agro forestry and Afforestation exercises. The body in its first model established a total of 9,591 compartments of windbreaks which were located in the following local government areas of the state: Jibia, Dutsin-ma, Kurfi, Bindawa, Mani, Mashi, Maiduwa, Katsina and Bataragawa. The second model of agro forestry adopted by the body was woodlot establishment. The body established a total of 6,421 compartments of woodlots in the mentioned areas of the state. In 1994, the EEC withdrew its funding of the project because of the unhealthy political climate in the country at that time. (Udofia 1992)

\subsection{Katsina Afforestation Project Unit/World Bank (KTAPU/World Bank)}

This organization was established in 1985, the agro forestry models introduced at that time were shelterbelts, woodlot, windbreak, Afforestation and farm forestry. This project was able to established a total of 21, 768 compartments of windbreaks in different parts of the state. (World Bank 1989)

\subsection{The Afforestation Programme Funded by International Bank for Rural Development (IBRD)}

This farm forestry and Afforestation project was financed by the International Bank for Rural Development and about 3.4 million seedlings were produced and distributed across the sahel region (Federal department of Forestry 2000). As at 2014, Afforestation and Agro -forestry related challenges on the environment in Katsina were been tackled by both the Department of Forestry and the Katsina State Afforestation Project Unit.

\section{Major Challenges of Afforestation Policies in Katsina State}

Afforestation policies and programmes in Nigeria today are mostly limited to government obligations. All the Forest reserves, which form the buck of the nation's productive forest, are under the management of the states or local Government. This is also the case with Katsina state. A careful look at all the policies and programmes aim at checking the dangers posed by climate change in Nigeria and Katsina state in particular are more or less titled towards practices that alienated local managers and populace from actual direct participation and involvement from conception to implementation. It is also worthy to note that almost the policies or programmes have terminated for one political reason to another.

As at 2014, only the Katsina state Afforestation Project Unit (KTAPU) exist without fully achieving the goals for which they were set-up other than the ones mentioned earlier. This is why this study is advocating a close coordination of Afforestation policies, devoid of politics and political which hunting. There is the need for a close harmonization and liaison of policies and programmes between the Katsina state Afforestation project Unit, Department of Forestry, ministry of Environment and Agriculture as well as local government's Natural resources sectors for a meaningful achievement to be recorded in fight against desert encroachment in the state.

\section{Statistical Data of the afforestation Project in Dabawa \& Darawa of DUTSIN-Ma Local GovernMent Area OF Katsina State.}

Table1. Dabawa Tree Planting Project

\begin{tabular}{|l|l|l|}
\hline Year of Project & Number of Tree Seedling & $\begin{array}{l}\text { Survive Tree Seedling as at } \\
\text { December 2013 }\end{array}$ \\
\hline 2010 & 5,000 & 2,458 \\
\hline
\end{tabular}

Source: Department of Forestry Katsina state June (2014)

Table2. Darawa Tree Planting Project

\begin{tabular}{|l|l|l|}
\hline Year of commencement of Project & Number of Tree Seedling Planted & $\begin{array}{l}\text { No. of Seedling Survive as at } \\
\text { December 2013 }\end{array}$ \\
\hline 2010 & 5,000 & 2,455 \\
\hline
\end{tabular}

Source: Department of forestry, Katsina state June (2014)

International Journal of Political Science (IJPS) 
The indications in table one shows that of the 5,000 Tree seedlings planted in Dabawa area of DutsinMa local government. In 2010, only about 2,458 trees have been nurtured and survived by the end of 2013.

In Table two also, in Darawa area of the Afforestation project embarked upon in the same year of 2010 , with equally 5,000 Tree seedlings, only about 2,455 have been nurtured and survived by the end of 2013.

A number of factors have been identified to have been responsible for this situation. To begin with the dependent of the rural populace in the Dutsin-Ma area on trees for both domestic and other uses is unlimited (Mohammed, 2013)- According to Daura (2012) some of the trees in the area provide medicinal properties for the local populace. Trees have crucial values to human beings not only for the resources they provide, but for the balancing of the ecosystem. According to World Bank 2010 report, almost about 1.6 billion people in the world rely on Forest resources for their livelihood (World Bank, 2010). Trees and Forest in sub-Saharan Africa constitute the source of income, life support and means of survival for the poor people (mogaka et al, 2001) particularly in periods of hardship.

Incidentally, these trees and forest have equally been a good source of checking the menace of Desert encroachment in the Sahel region. In Dutsin-ma, the agrarian nature of the rural populace and Nomadic herdsmen practice also has taken its toll on the effort of the Katsina state Government in its efforts at combating the problem of desertification in the local government area.

We observed from our finding as provided in Table 1 and 2 that the activities of the local populace in using some of these trees meant for encouraging Afforestation and reducing the problem of desertification for domestic purpose as fuel wood for cooking is a problem. The activities of herdsmen and their cattle or livestock have also not helped matters as most of these trees have been destroyed by the animals. This is a worrisome situation for both the success of the aim and objectives of the Afforestation project and the curbing of the issue of desertification in the local government area and Katsina state in particular.

\section{Conclusion}

The finding of this paper shows that the type of policy approach and the nature of politics go a long way in shaping the success or otherwise of environmental and climatic combating strategies. The state government has tried so far as we have noted in this paper, but more effort still need to be done in that regards as the problem of desertification has continued to pose a great challenge to the state government and the Nation at large. The paper also observes that concerted efforts must be made to integrate the rural populace in seeing these afforestation programmes as part of safeguarding the environment for the overall benefit of all and sundry, these policies should also be devoid of politics or political witch-hunting.

\section{RECOMMENDATION}

Politics and policies can either facilitate or obstruct sustainable forest management through the activities and influences of politicians, leaders, bureaucrats, activists among others. For this reason, it is necessary to build a strong political will and commitment to the Afforestation programmes with an enhanced sustainable backing from the government and all other stake holders concern.

The Katsina state government should continue to key into the national policies of the federal government in ensuring that the menace of Desert encroachment is checked through a sustained programme of Afforestation.

Efforts should be made by the Katsina state government to restock the two Afforestation projects at Darawa and Dabawa in Dutsin-ma local government area to help sustain the efforts so far achieved in checking the problem of Desertification, in the area. This should also be accompanied with a proper management plan designed and administered by qualified foresters or staff of the Department of forestry.

The local host community of the Afforestation project in Darawa and Dabawa area of Dutsinma local government should be mobilized and enlightened on the role of the Afforestation projects in helping 
to check the menace of Desertification and not just for fuel wood supply and grazing leaves for livestocks.

This will in the long run go a long way in helping to combat the problem of climate change not just for Dutsin-Ma area alone, but for the world at large.

\section{REFERENCES}

Abaje, I.B. Ogoh. A.O. Amos, B.B. and Abashiya, M. (2015) Climate Change, Flood Disaster Assessment and Human Security in Katsina State, Nigeria. American Journal of Human Ecology Vol. 4, No. 4, 2015, 47-56 Published by World Scholars http://www.worldscholars.org

Abbas, D(2007) Harvesting Forest biomass for energy in Minnesota: An assessment of guidelines, cost and logistics. PHD Dissertation, University of Minesota USA.

Boon, E \& et alls (2009) An Assessment of Forest Resources Policy \& management in Ghana; a conference paper presented at the IAIA09, conference proceedings Accra Ghana.

CBN (2012) Report on GDP Domestic forest contribution FGN.

Daura U.S. (2012) An Assessment of Tree Density \& Diversity on small holder Farmed Parkland in Daura. Unpublished MSC Thesis submitted to the Department of Geography Bayero University Kano, Nigeria.

Department of Forestry, Katsina state (2014). Information Unit.

Federal Depart of Forestry (2000) - Nigeria Country Report on Forest Management in Niger FGN.

FRN (2007) Federal Republic of Nigeria (FRN) official Gazette. No 24, Vol. 94. Federal Government Printers Lagos, Nigeria.

Haruna (2010) High Forest management in Nigeria, IUTRO conference Eborsiraide Germany.

Katsina state Ministry of Agriculture (2004) Bulletin on Afforestation Projects; Ministry of Agriculture, Katsina state.

Mohammed I A (2013) Shelterbelt and Farm Forestry drive for successful Afforestation. In Akinsanmi F.A(Ed) our forest, Environment and Heritage; Challenges for our people. Forestry Association of Nigeria(FAN).

Mohammad N D an et alls (2014) Challenges and prospects of Tree seedlings production in katsina state of Nigeria IOCR Journal Vol.19. Issue 4.

NPC (2006) National population Census 2006, FGN Abuja.

Sackey, (2007) Forest revenue system in a changing world. Cambridge, M A MIT Press.

Udofia, S.I (1992) Project Summary Greenlight magazine. ECC/FGN, Katsina Afforestation Project.

Wikipedia (2014) Dutsin-ma local government @ en.wikipedia.org. retried August 8, 2014.

World Bank (2010) http://wblu0018.worldBank.org /news/ Press release not retrieved Aug 6, 2014. 